\title{
John Nolen and Raymond Unwin: Garden City Collaborators
}

\author{
By Michael O'Brien*
}

The English Garden City Movement, advocated by Ebenezer Howard and the associated town designs by Raymond Unwin were some of the earliest reactions to the environmental degradation and placelessness of the European Industrial City circa 1900. John Nolen (1869 - 1937) was one of the earliest American adopters of the Garden City ideals. Over the course of his career, Nolen designed fifty-five new towns and subdivisions across the United States. Most of these plans had elements that were adapted from Sir Raymond Unwin's principles and spatial conditions to fit the unique cultural landscape of the emerging American middle class. Placemaking was one of the central goals of the Garden City. Places, at multiple scales, town, neighborhood, and street distinguished the Garden City from the monotonous and chaotic landscape of most cities. A unique characteristic of the planned communities and subdivisions by Nolen is that they demonstrate the potential of integrating landscape architecture, architecture and planning principles to construct an underlying infrastructure of placeanchors, to guide place-making during build-out phases, even when build-out occurred decades later. Plans designed by Nolen's firm after 1920 characteristically included strong formal elements, central greens, axial boulevards and a hierarchy of spatial conditions extending from the town center to the thoughtful termination of a residential street. These post-1920 plans showed what I am calling "place anchors" that established landmarks at the scale of neighborhood, district, and town. This paper will present a comparative study of the "as designed" and "as built" conditions of two projects designed in the early 1920's and "built-out" in the competitive post-depression economy of the late 1930's. The projects, in Mariemont, Ohio and at Windsor Farms, Virginia, are the result of John Nolen's unique transformation of Garden City principles to fit the landscape of the emerging American suburb.

\section{Raymond Unwin and Early Ideas on Place Making in Towns}

Sir Raymond Unwin, a leader in the Planning and Garden City movements described a number of design-related planning considerations on the subject of

${ }^{*}$ Professor, Texas A\&M University, USA. 
place making in his 1909 book, Town Planning in Practice." "Much of the picturesqueness of old Gothic towns springs from the narrowness of the streets. Not only does this narrowness give the sense of completeness and enclosure to the pictures in the streets themselves, but also it is much easier with such narrow streets to produce the effect of enclosure in a place into which they may lead. Where roads are wide and bounded by small buildings, the definite street effect is apt to be lost altogether, the relation between the two sides is not sufficiently grasped, and on such roads some quite different effects may need to be worked out, if they are to be successful."2

"We have seen in speaking of places and squares how important to the effect is a sense of enclosure, the completion of the frame of buildings; and much the same applies to street pictures."

These quotes and further citations from Unwin confirm that he was learning from Camillio Sitte's "City Planning According to Artistic Principles", (Unwin, 1909) and clearly recognized the necessity for design of the spatial enclosure and sequence of release into urban places. ${ }^{4}$ Place, in his examples is represented by abrupt enlargements of the space formed by the street such that it is possible to perceive that one is not in a linear space suggestive of motion, but in a space proportioned more equally in its length and width to suggest pause. Unwin specifically illustrated the planning principles underpinning these picturesque streets in "Town Planning In Practice," Chapter Nine "Of Plots and the Placing of Buildings." 5 Unwin illustrates in plan and perspective, the effect of manipulating the location and orientation of buildings relative to adjacent buildings and the street. Unwin's examples addressed three general conditions:

1. Intersections.

2. Street space between intersections.

3. Visual control of sight lines on curving streets.

Unwin used plan diagrams and perspective sketches to illustrate various ways of working with these conditions. He consistently sought to maintain the uniformity of rooflines and the visual enclosure of the street by using building mass to contain the street space and then releasing it in carefully considered locations. This heightened the sense of street enclosure provided by the small, detached houses and yields the maximum spatial impact. As a strategy to further enhance the spatial definition of the street, Unwin emphasized using the group house, or attached type of row house, to overcome the space-defining limitations of small single-family detached houses. As he put it, "In residential districts one of the greatest difficulties to be contended with is the constant

\footnotetext{
${ }^{1}$ Unwin, Sir Raymond, "Town Planning in Practice: An Introduction to the Art of Designing Cities and Suburbs" Charles Scribner \& Sons, New York, 1909.

${ }^{2}$ Ibid p. 245.

${ }^{3}$ Ibid p. 245.

${ }^{4}$ Ibid p. 215.

${ }^{5}$ Ibid p. 319.
} 
multiplication of buildings too small in scale to produce individually an effect on the road, and every opportunity should be taken to group buildings so that units may be produced of larger scale." "Even where it is not possible to avoid much repetition of semidetached or detached houses, they should be arranged to give some sense of grouping."7

Unwin as both architect and planner saw a critical overlap between planning, landscape architecture and the architecture professions. “...especially where it is possible for the site planner to be in touch with the designer of the buildings, much may be done to produce interest and variety in the street pictures, while at the same time maintaining the general sense of unity which is usually so wanting in modern suburban roads." "For Unwin the appropriate allocation of areas for public use, road width, and control of land use was not alone sufficient to make a town.

Buildings are the space-bounding elements in Unwin's examples. In the European model of the village, upon which Unwin based his principles, the urban street was built to such a density that the streets are bounded by the nearly-continuous walls of adjacent buildings. One may conclude that while Unwin's design goals for the carefully constructed picturesque were clearly a source for the designs by John Nolen and his firm, a significant transformation of design elements was necessary to apply these principles to the lower density American suburb.

\section{Place in the Plan: The Intersections}

Beginning around 1920, the office of John Nolen began to employ a unique overlay of formal/axial street patterns from the City Beautiful movement and the informal, curvilinear street patterns of the Garden City Movement. In the Nolen firms' plans from 1920 to the firm's dissolution in 1934, places are nested in a hierarchy to reveal successive layers of distinction.

"My corner" may be found in the larger ground, the "my school" neighborhood, while both are figures in the yet larger ground of "my town."

Intersections of major and minor streets are the primary place making figures in these Nolen plans. The lots between the intersections play the role of ground establishing a more dense spatial enclosure punctuated/articulated by schools and parks acting as second layer of place-anchors and neighborhood greens, "T", "X", "Y" and "+" intersections as a tertiary layer of place-anchors.

I have characterized these place-anchoring residential conditions as: (See Figure. 1)

"Face the intersection" a condition where houses at "Y" or irregular "T" intersections orient to the actual center of the intersection rather than maintaining a parallel relationship to their streets.

"The street room," a condition where houses at the end of a long straight street have a smaller setback, forming a gateway or defined entrance to the block. Houses along this street have setbacks that increase incrementally so as

\footnotetext{
${ }^{6}$ Ibid p. 350.

${ }^{7}$ Ibid p. 350.

${ }^{8}$ Ibid p. 351.
} 
to make the space of the street, defined by the house fronts, wider at the center and narrower at the ends. This widening tends to reduce the sense of the street as a "corridor" to be hurried through, and enhances the quality of the street as a "room" in which to reside.

The "axial terminator," a condition on a dead-end street or " $\mathrm{T}$ " intersection where the house, church or other building is centered on the street forming a visual termination of the street space.

The "split lot termination," is a condition on a dead-end street or " $\mathrm{T}$ " intersection where the lot lines are centered on the street. This has the effect of letting the street space continue through the plane established by the fronts of the houses. Nolen sometimes used this design to establish the place for pedestrian paths through the street-front property to a green, park, or tennis court in the middle of the block.

Figure 1. Place Anchoring Residential Conditions (by Author)

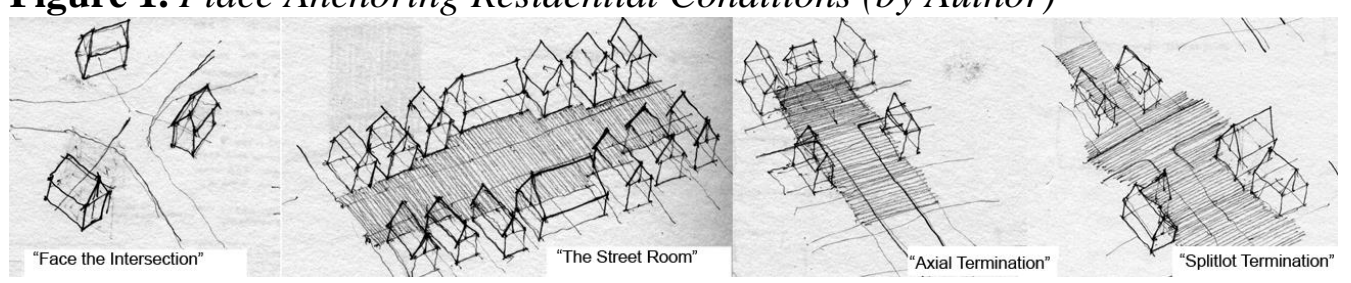

The goal of physically planning street width, lot dimension and location, landscape, and architectural character, is to allow a person to sense "a particularly agreeable location in the urban scene which is treasured in memory and to which there is a desire to return", as Arnold Whittick put it, a place. ${ }^{9}$

Nolen's office employed carefully sited architectural elements in concert with arcades of large shade trees to define the street space to a degree similar to that proposed by Unwin. Like Unwin, Nolen paid particular attention to making public place at intersections. At " $T$ ", " $X$ ", " $Y$ " and "+" shaped intersections, Nolen and his associate Philip W. Foster carefully located lot lines to encourage architects and contractors to site the building mass on the lot to define the street space according to the planners design intention. Indeed, Nolen and Foster went even further in some projects, drawing the axis of symmetry on the plan and suggesting the orientation of building masses to heighten the spatial effect (See Figure 2).

${ }^{9}$ Whittick, Arnold, Encyclopedia of Urban Planning, McGraw Hill, NY, NY 1974. 
Figure 2. Mariemont Plan Excerpt Showing Fieldhouse, School, and Houses Terminating the Streets Footprints. Permission by Kroch Memorial Library. (Accession 2903 Drawer 3 Rare and Manuscript Collection, Carl A. Kroch Library, Cornell University, Ithaca, New York.)

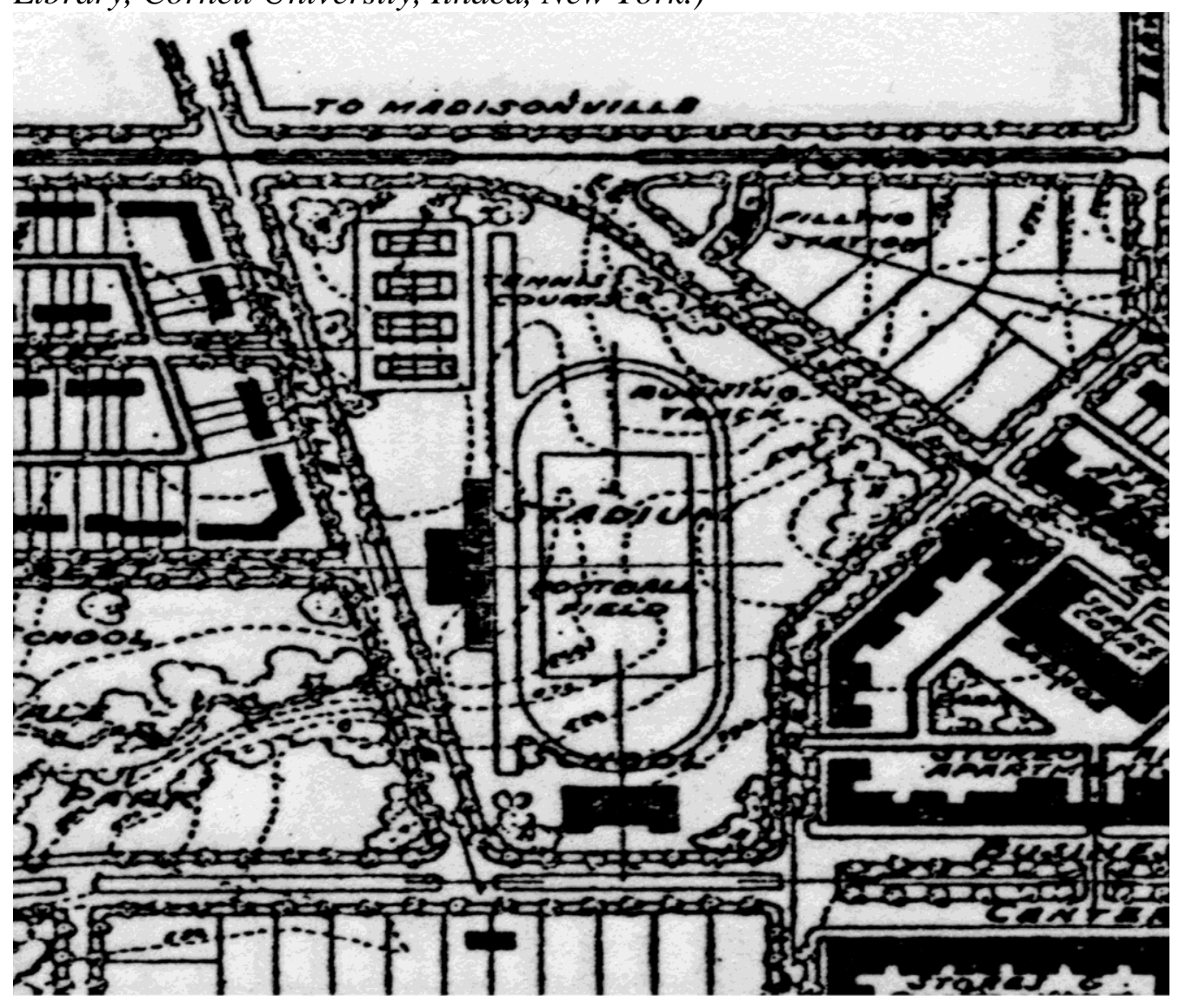

\section{Mariemont, Ohio 1920 - 1925}

Mariemont, Ohio is Nolen's flagship American Garden City. Mariemont was developed for the Mrs. Mary Emery, widow of a successful Cincinnati businessman who sought to address the problems of quality in community and housing affordable to lower and middle-class Americans. Her trustee, and Mariemont's project director, Charles Livingood researched the English Garden City in numerous trips to Welwyn, Letchorth, and Port Sunlight, attended the national planning conference organized by Nolen, and ultimately hired the firm in 1920 to design "A National Exemplar" model city that would incorporate all the successes of the Garden City. As such, Mariemont includes limited profit properties, designed to attract a broad mix of incomes, district heating, hospital, shops, farms, and power plant - a complete community infrastructure linked by mass transit to Cincinnati. ${ }^{10}$ Livingood's purchase of over 300 acres gave Nolen more control look and feel of the plans layout and landscape. Nolen's recommendation that the developer retain architects sharing

\footnotetext{
${ }^{10}$ Rogers, Millard F. Mariemont: building a new town in Ohio, Johns Hopkins University Press, Baltimore, MD 2001.
} 
similar design ideals contributed to furthering Nolen's vision for Mariemont, integrating plan, landscape and building during the initial design and build-out.

The site for Mariemont is low rolling hills on a bluff overlooking the Little Miami River containing the crossroads for the Plainville and Wooster Pikes. The site is further contained by a trolley line to Cincinnati on the North, and the Norfolk and Western Railroad below the bluff, along the banks of the Little Miami River on the southern edge of the site. Like many of Nolen's projects, the design process seems to have begun by formalizing a prominent feature of the existing site. At Mariemont, this is the crossing of the Wooster and Plainville Pikes. These roads were slightly re-routed to cross as an elongated " $X$ " shaped intersection. Nolen overlaid a small green at the center of this " $\mathrm{X}$ " and formed the town center around it by massing shops and public institutions to visually anchor the center as a highly defined public space. From this primary " $\mathrm{X}$ " intersection, Nolen extends a formal boulevard east and west, through the town center. Then develops a north-south boulevard commencing at the "back" of the town hall (which "fronts" on the Town Center space) extending to the axial termination at the concourse and overlook to the Little Miami River on the southern edge of the site (See Figure 3).

Figure 3. Mariemont Overall Plan. Permission by Kroch Memorial Library. (Accession 2903 Drawer 3 Rare and Manuscript Collection, Carl A. Kroch Library, Cornell University, Ithaca, New York.)

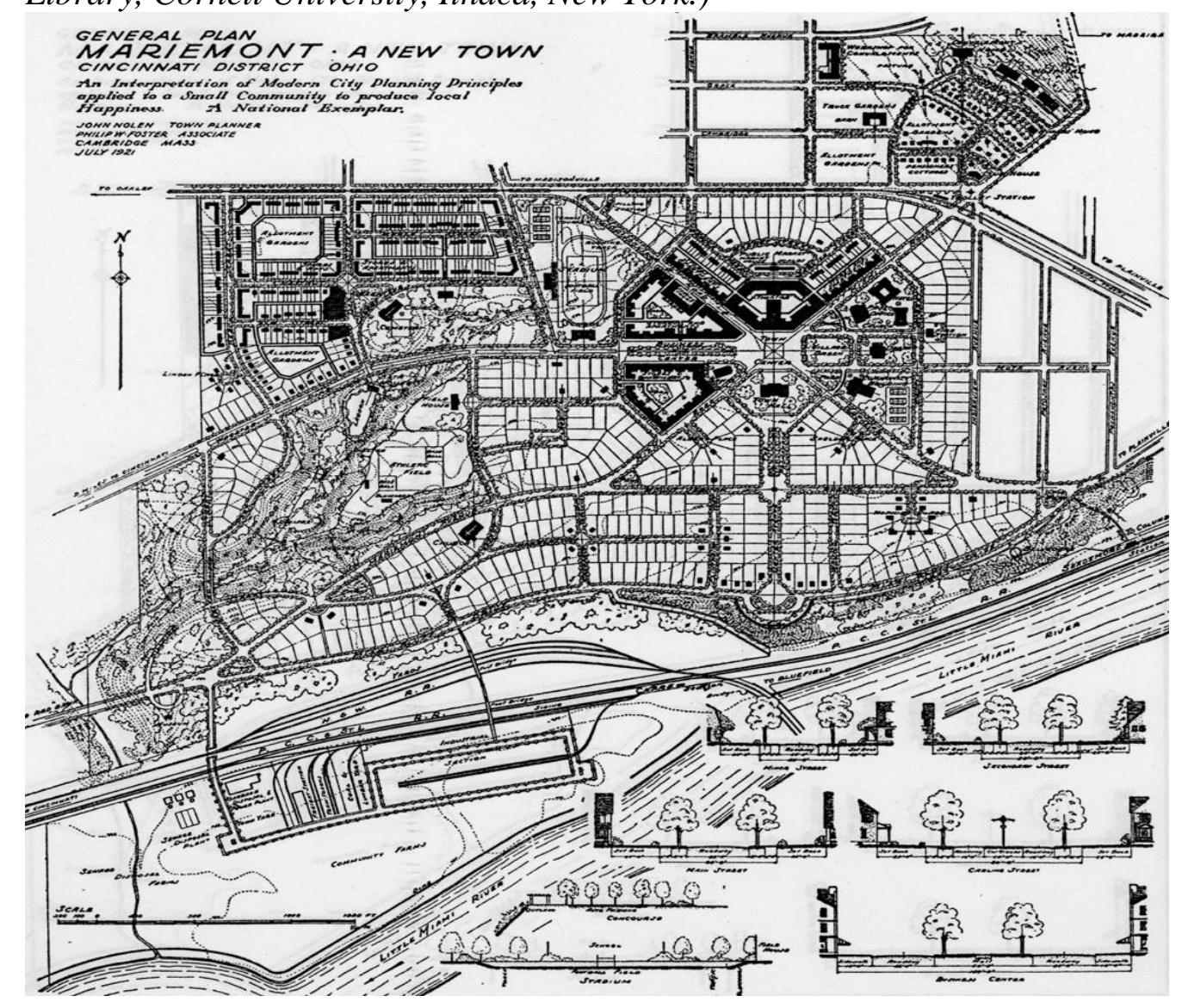


The clearest examples of place-anchoring practices employed by Nolen and Foster can be found on the drawings for Mariemont. At Mariemont, Nolen's high level of control over the selection and practices of the town landscape architect, lead architect, and participating architects resulted in commercial and institutional buildings constructed in close conformance to the axial siting and space definition shown on Nolen's plans for Mariemont's town center. $^{11}$ The residential districts, built-out between 1925 and 1950, were not constructed in as close-conformance with Nolen's plans.

The plan for Mariemont skillfully combined curvilinear, diagonal, and grid structures to prevent the endless open street vista, common to most grid-plan cities. As Unwin demonstrated, the curvilinear street created vistas that were always changing and limited to the length of the curve's tangent from traffic lane to the front of the buildings. Nolen was not able to replicate the building massing that provided Unwin with fully bounded spatial "street pictures" and so employed large shade trees to provide the primary spatial boundary of the street. Houses at Mariemont provided a secondary spatial enclosure for street and public spaces. As such, the centerline of the house or building, at key places in the plan, would often be included on the drawings, and frequently generalized building footprint would be shown. These hints were backed up by design review guidelines at Mariemont that limited style, material, and site location.

The July 1921 plan for Mariemont contained design intentions for 19 of the 20 proposed residential street intersections. Aerial photography indicates, and field-surveys confirm that only five of those intersections were fully constructed as designed. These five, were simple spatial conditions, the termination of a visual axis formed by the street, reinforced by mature shade trees and completed by the prominent siting of a house to center the mass on the centerline of the street. That these simple plan intentions were realized in the decades of build-out following the plan design may be due to the close association to normal builder practices, centering the house on the lot, used for residential siting. Many of the remaining designed residential place-anchors required more complex rotations of the house to orient the front of the house towards the invisible center-point of irregularly shaped " $Y$ " and " $X$ " intersections, a practice further from the norms of residential siting practiced by builders.

The network of residential, commercial, and institutional place-anchors designed by Nolen is sufficiently dense as if to suggest it is scaled to the pedestrian journey. Visual connections between places and the changes in spatial scale between lane, street, road, and boulevard seem more oriented to the person on foot, than the person in a car. The car would seem to suggest longer distances between places as it takes less time to traverse. A person's short-term memory or journey-memory capacity seems to be fixed. If we travel

\footnotetext{
${ }^{11}$ Venice, Nokomis, Clewiston Florida and Windsor Farms, Virginia seem to share this structure.
} 
on foot, the landmarks need to be closer together to allow us to judge our position on the journey. If we travel by car, the landmarks could be farther apart but still fall within the time we hold landmarks in our journey-memory. One of the ways I propose that we judge the richness of a town or city is in the places per mile (PPM). The ubiquitous commercial strip we encounter so frequently today may be perceived as placeless because the visual competition by each store/mall to be a landmark dulls our ability to perceive any landmark places, this combined with the car-scaled eight-lane roads and thousand-car parking lots, reduces our perceived places per mile.

Old Town Alexandria, Boston, Wrigleyville in Chicago or most every city developed before the automobile was dominant, like Mariemont, offers a sufficient density of places-per-mile traveled that many people perceive these towns as pedestrian-scaled. ${ }^{12}$

In the Virginia and Florida projects that followed Mariemont, Nolen and Foster had less institutional control over residential siting and planting, but did possess control over the space of the intersections and the termination of visual axes through careful design and layout of the lot lines.

\section{Windsor Farms}

The Windsor Farms project is a 442-acre development with 448 saleable lots immediately west of downtown Richmond, Virginia designed by John Nolen and Associates in 1924 for the T.C. Williams Development Company.

Unlike the highly advertised and publicized Mariemont, only two drawings (ink on linen) of the Windsor Farms development survive and are in the Nolen Collection of the Kroch Memorial Library at Cornell University. The first plan is dated June 1924 and a revised plan dated November 1924. The Nolen collection contains no correspondence referring to either the early plan, or the client's perceptions of strengths and weaknesses that resulted in the revised plan being developed.

The June and November 1924 plans are quite similar in structure characterized by overlain diagonals and cross axial roads upon two strong concentric ovals with local institutions clustered around the town center, Windsor Common, a green centered above the crossing of the axial roads. (See Figure. 4) The 442-acre site is located on a bluff overlooking the James River. The project is bounded by Carey Street on the North, South Locke Lane on the West, the James River bluff on the South, and route 76 / interstate 195 on the East.

\footnotetext{
${ }^{12}$ This is conjecture on my part made only through observations as both pedestrian and driver in Mariemont, Ohio, Windsor Farms, Virginia, Venice, Florida, and Nokomis, Florida. The downside of the high number of places per mile in these Nolen-designed towns is that it is an almost overwhelming experience as a driver.
} 
Figure 4. Windsor Farms Overall Plan. Permission by Kroch Memorial Library. (Accession 2903 Drawer 3 Rare and Manuscript Collection, Carl A. Kroch Library, Cornell University, Ithaca, New York.)

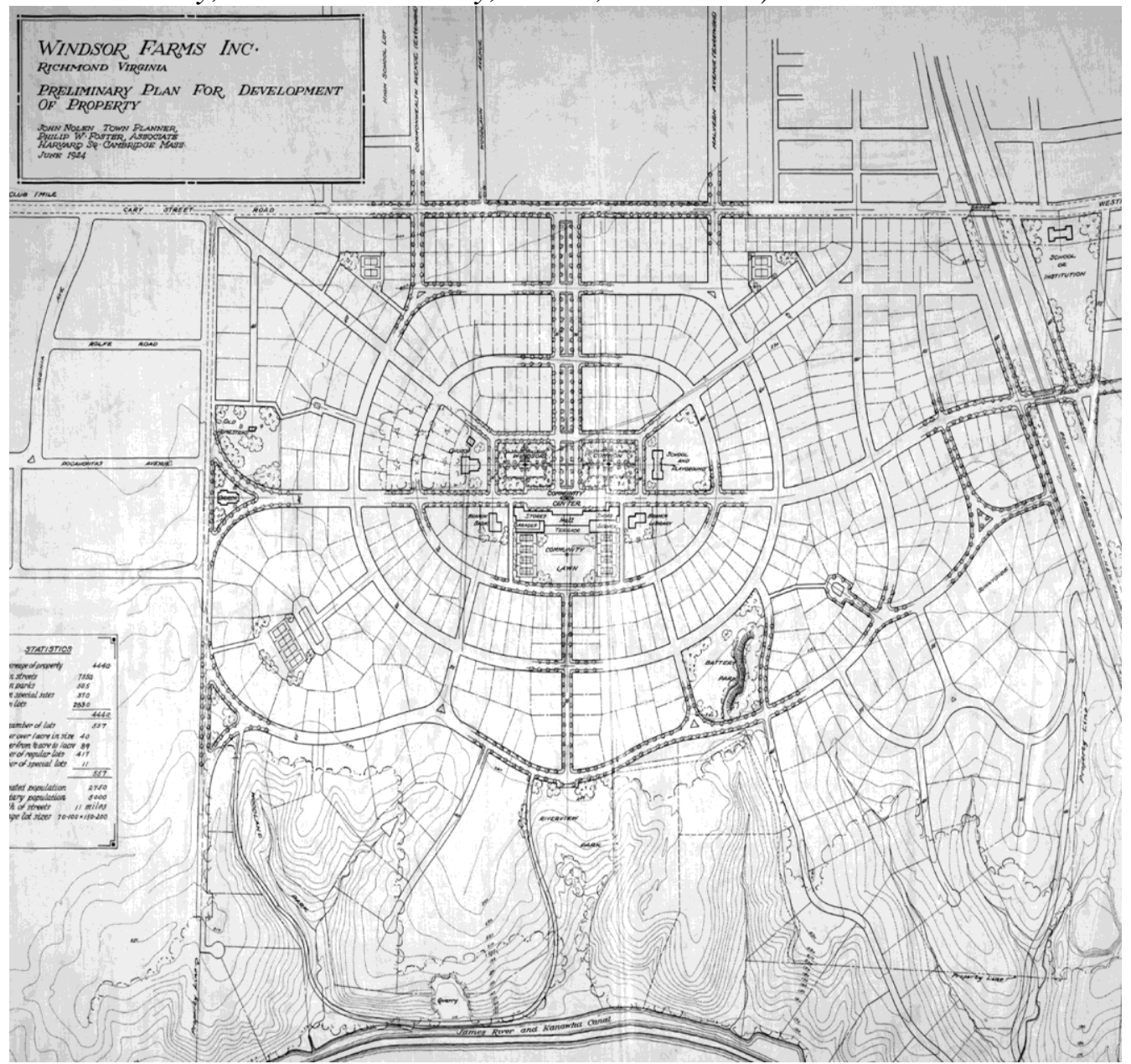

As in many of the subdivision and new town designs by the Nolen firm, there is a clear hierarchy of width and amenity visible in the road types. (See Figure. 5) Both the June and November schemes are anchored by a central green-space. Windsor Way is the major street extending from the green north to Carey Street. Wakefield Boulevard is the major street extending south from the green to the river bluff, and the major street extending from the eastern to the western property edge is Dover Road. 
Figure 5. Road Types Diagrams. Permission by Kroch Memorial Library. (Accession 2903 Drawer 3 Rare and Manuscript Collection, Carl A. Kroch Library, Cornell University, Ithaca, New York.)

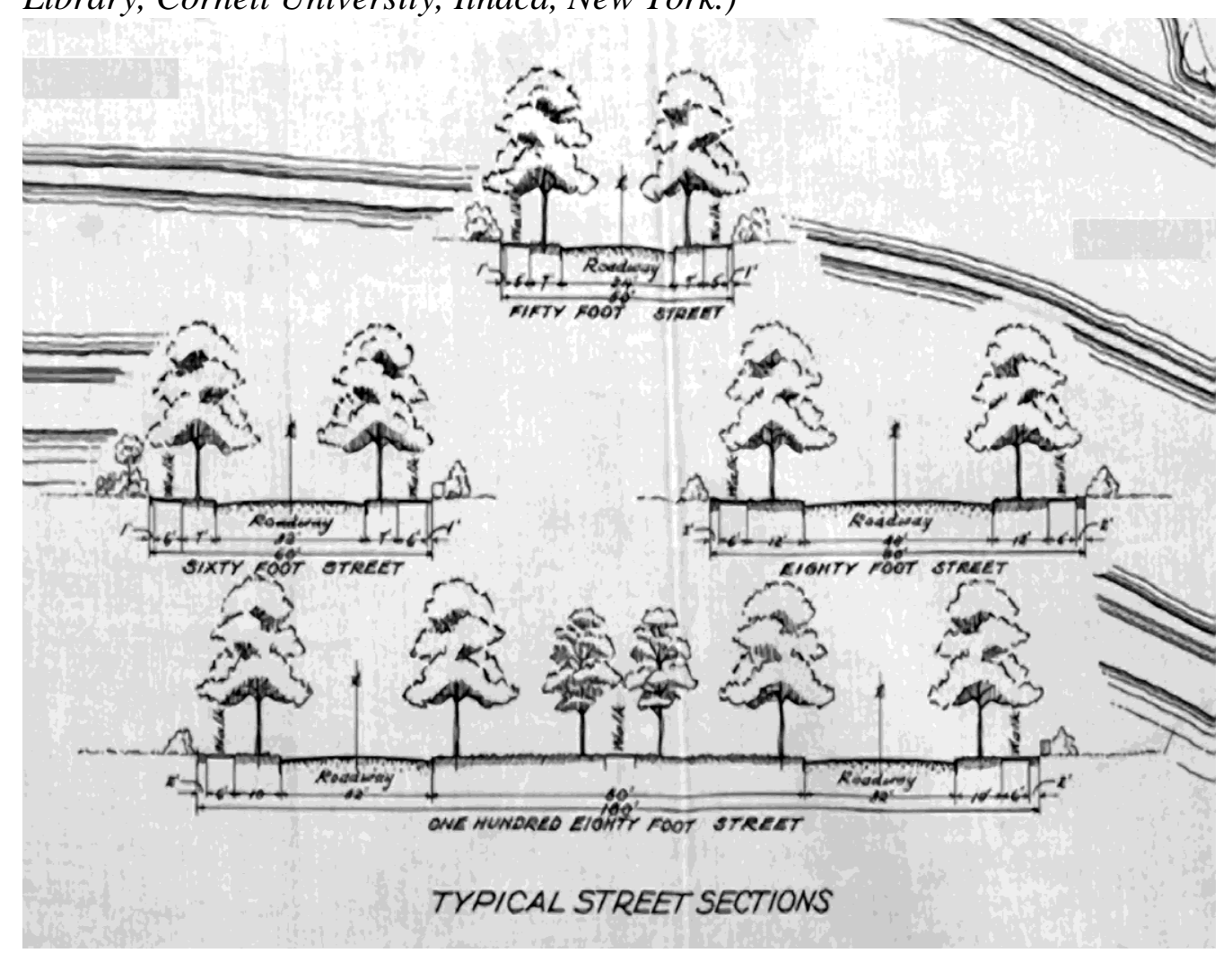

Like Mariemont, it seems Windsor Farms is structured by Nolen's formal connection of the primary features of the site. Nolen connects Carey Street to the James River bluffs by extending a north-south boulevard from Carey Street to the green, Windsor Common. As at Mariemont, Nolen interrupts/terminates the boulevard at the town center, Windsor Common and its surrounding public buildings, then continuing the connection from the "back" of the green to the river overlook with a formally landscaped street, Wakefield boulevard. Also similar to Mariemont, an east-west cross axis is developed along the back edge of the green. Two concentric oval roads overlay the cross axis and substantially fill out the site.

\section{Landmarks as Place-Anchors:}

The site for Windsor Farms has one primary natural feature, the James River bluff, two historic features, Windsor, the original homestead of Martha Washington's nephew, William Dandridge, and an earthworks constructed to house a cannon battery during the Civil War. Nolen further employs these historic features of the site, centering Calycanthus street on the reconstructed "Windsor" homestead, honoring it as a termination of a visual axis, (See Figure. 6) and terminating the minor southeast diagonal street at the batterypark. 
Figure 6. Integration of Historic "Windsor" Homestead

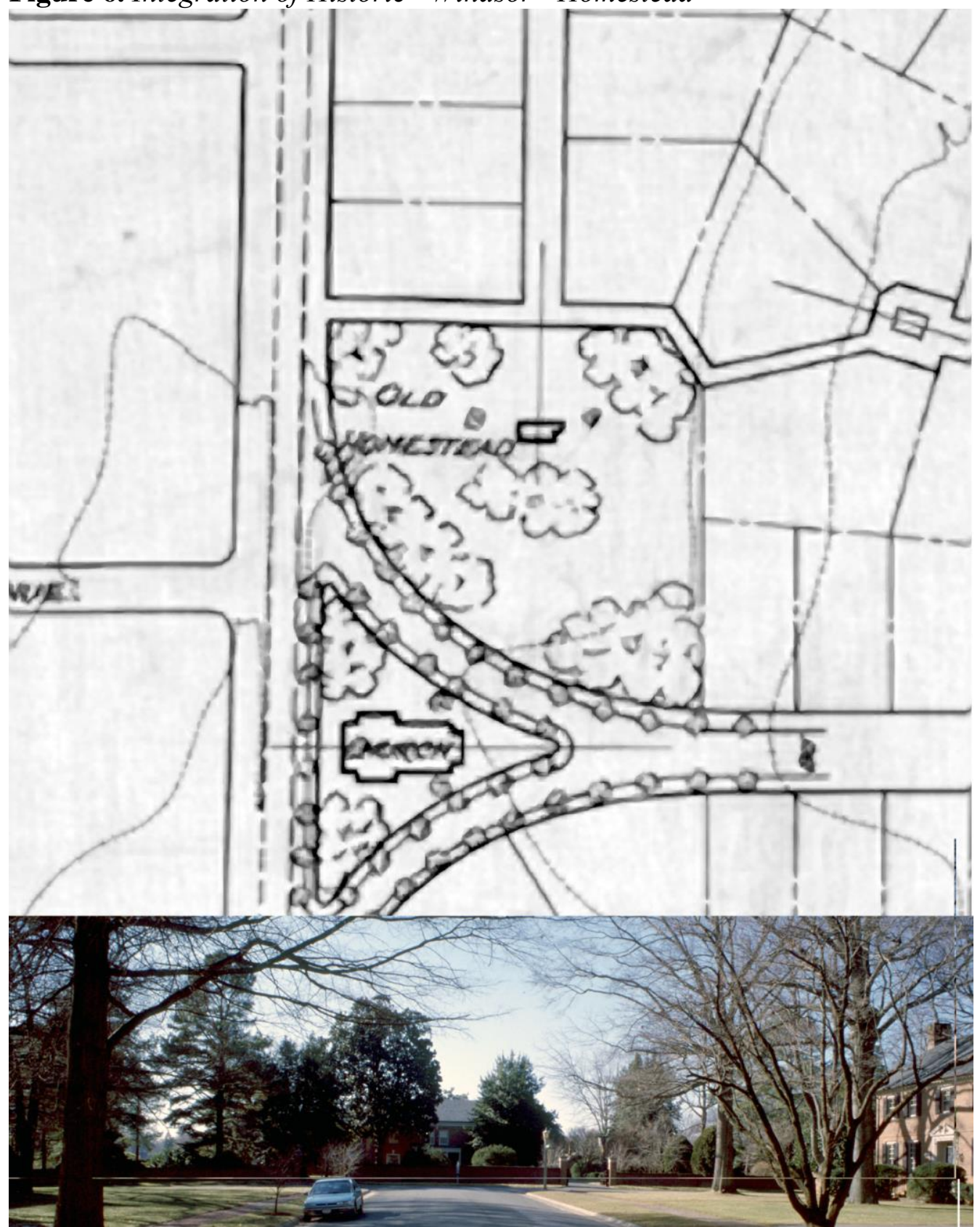

Unlike Mariemont, the Windsor Farms site was attached to an existing city structure. Nolen's design works to connect to the adjacent city with two devices, the northwest diagonal extending from Windsor Common to Carey street, visually terminating at an existing church, and the other a bridge from east-west axis across the expressway to the neighborhood beyond.

Combined with these urban, natural and historic landmarks, the revised November plan includes places for five small parks, two schools, a church, small shops and a public hall. Of the fifteen public institutions ranging from parks to churches, libraries and two schools shown on the initial June plan 
while only nine are included in the revised November plan. In both plans, these public institutions are generally treated as landmarks and visual terminations of axis. Unlike Mariemont, Nolen's drawings for Windsor Farms show no indication of siting orientation or massing for housing.

\section{Suggestions to Future Builders Unknown:}

Unlike his role at Mariemont, Nolen had little control over the programming and initial build-out at Windsor Farms. He expressed this concern to the developer T.C. Williams directly and indirectly to Henry Morse, a New Jersey Architect working on the house for T.C. Williams at Windsor Farms. In a letter to Henry Morse Nolen expressed concern for the architectural progress of the development as a whole. He complimented Morse on his work for Williams and sent him a brochure on Mariemont, citing it as an example of following through on the character of the plan (Nolen, 1926) Nolen was perhaps hoping Morse would advocate a controlled approach to style and design in Windsor Farms in the course of his conversations with T.C. Williams about the house. ${ }^{13}$ Perhaps Nolen's concern for architectural follow-through is behind the level of detail included for proposed buildings shown on the plan.

At Windsor Farms' central space, a solid block identified as "stores" on the western side, "hall" in the center and "shops" on the eastern side receive and terminate the Windsor Way visual axis along the southern edge of Windsor Common. The center of this block, labeled as "hall" has a recess, roughly as wide as the Windsor Way Boulevard. This recess is the planner/landscape architect's suggestion to the future architect and builder that the massing of the "hall" should receive Windsor Way with a massing recess. The stores and shops adjacent to the central hall are wrapped slightly around the corners of the southeast and southwest diagonal roads. This is another suggestion from planner to, future architect/builder, as a reminder that the role of the corner is to compress the space, acting as a frame for the release to Windsor Common itself.

Neighborhood centers such as this were frequently proposed by Nolen's office, but were less frequently constructed. This may be due to a misunderstanding between the developers expectation, i.e. Nolen will lay out streets and lots for residential neighborhoods, and Nolen's expectation, i.e. "this developer retained my firm to plan a neighborhood that will offer residents ready access to shops for daily needs, schools and churches." Mariemont has the strongest example of a constructed neighborhood center, while the many such centers shown on the various drawings for Kingsport Tennessee and Nokomis, Florida failed to materialize. At Windsor Farms even the significant reduction of the neighborhood center between the June and November plans was not enough to insure its construction (Nolen 1922).

\footnotetext{
${ }^{13}$ Letter from John Nolen to Henry Morse dated April 20, 1926. (Accession 2903 Box 66, Windsor Farms File, Rare and Manuscript Collection, Carl A. Kroch Library, Cornell University, Ithaca, New York.)
} 


\section{Street Hierarchy}

Even given the loss of the neighborhood center during the build out phase the hierarchy of street rights-of-way closely corresponded to the widths and landscape densities shown on the November plan. Windsor Way, the boulevard connecting Windsor Common in the center of the plan to Carey Street to the North is the widest street in the plan. The right-of-way for Windsor Way is one hundred and forty feet in width making it the widest in the development. Next widest is Dover road, the major east-west street, at eighty feet wide. Wakefield Road, falling on the central North-South axis and connecting the central ring road, Oxford Circle with the outermost ring road (variously Berkshire, Sulgrave, and Cantebury Roads) is also eighty feet in width. The major diagonal roads, Coventry and Exeter both have a sixty-foot right-of-way, while the minor diagonals, Avon and Hathaway, are a fifty-foot right-of-way. The smallest right-of-way, forty feet, belongs to Clovelly Road, Long Lane, and St. David's Lane.

The preservation of the street rights-of-way hierarchy, and close conformance to the landscape massing as shown on the revised November plan substantially preserve the spatial qualities of containment and release that appear to have been Nolen's primary intention.

\section{Build-Out}

The later "build-out" phases for Nolen and Foster's Mariemont, Ohio project overlaps the Windsor Farms project by three years or so. As was often the case design of the individual lots and control of building placement on the lots was a primary method for assuring that the "build-out" phase of the project would be consistent with the planned spatial character of streets. Nolen understood the primary role streets play in establishing the character of a place having frequently criticized the grid plan city for its endless vistas and inherent impersonal quality.

No guidance or limitations for residential siting appear on the drawings for Windsor Farms, in fact no drawings dated after November 1922 are to be found in the Nolen archives (Nolen 1922) There are references in the correspondence files to additional design work undertaken by associate Phillip Foster from the Jacksonville office, however, the Nolen archives do not include them.

Without explicit indications on the drawings, the more subtle and complex spatial conditions (inspired by Unwin) found at Mariemont are not to be found in great quantity at Windsor Farms. Perhaps the clearest residential placeanchor to be found in Windsor Farms lies at the intersection of Gun Club Road and Tomacee Street. Like those intended place-anchors that were realized during the build-out decades at Mariemont, this place condition is the simple termination of the Tomacee street axis at Gun Club road. Here, Nolen, or perhaps Foster adjusted lot dimensions to insure that a lot centerline would correspond with the street centerline, combined with the normal builder practice to center a house on its lot, a thoughtful termination of the axis occurs, without design controls and without a suggestion of massing on the plans. 
Another fragment of success lies at the intersection of Berkshire Road, the middle concentric oval road and Coventry Street, the major Northwest diagonal street connecting Windsor Common to the existing church on Carey Street. At the corner intersection between Berkshire and Coventry, two of the houses are rotated so that the center of their "face" is oriented to the invisible centerpoint of the intersection. Again, the drawings show no indication of a suggestion for residential massing or orientation and one can only speculate that the combination of lot shape, and Foster's site supervision may have resulted in this partial emphasis made on this important intersection.

\section{Conclusion, the Importance of Place-Anchors}

John Nolen's planned communities went through a key metamorphosis between early 1910 and 1921 adding layers of spatial intention to the already topographically sensitive schemes produced by the firm. The spatial intentions, imported from Unwin (Unwin, 1909) and transformed for the decreased spatial density of the suburb, was implemented primarily through control of street width and careful attention to landscape - particularly the street trees. The spatial intent was aimed at developing a hierarchy of "places" to counteract the pervasive "placeless" grid-planned neighborhoods common in developing American cities. The place hierarchy began with a community center having boulevards, open spaces, and community buildings that were at a much larger scale than the surrounding residential community. The second order in this hierarchy was the distribution of public greens and parks along major streets. The third order was the neighborhood place, a prominently sited house at the end of a street, or a sequential enlargement of the street setback to make a broader room on the narrow street, or the re-orienting of the houses away from the orthogonal intersection towards a diagonal orientation to the center of the intersection. These third order places were the most difficult to achieve for Nolen, as they would have required a level of property control that may have been perceived as restrictive to the point of reducing lot sales.

Table 1.

\begin{tabular}{|l|c|c|c|c|}
\hline \multicolumn{1}{|c|}{ Spatial condition } & \multicolumn{2}{|c|}{ Mariemont } & \multicolumn{2}{c|}{ Windsor Farms } \\
\hline Facing the intersection & $\begin{array}{c}\text { As } \\
\text { designed }\end{array}$ & $\begin{array}{c}\text { As } \\
\text { built }\end{array}$ & $\begin{array}{c}\text { As } \\
\text { designed }\end{array}$ & $\begin{array}{c}\text { As } \\
\text { built }\end{array}$ \\
\hline The street room & 6 & 4 & 0 & 8 (partial) \\
\hline $\begin{array}{l}\text { Axial termination with } \\
\text { enframing }\end{array}$ & 11 & 2 & 0 & 0 \\
\hline $\begin{array}{l}\text { Axial termination } \\
\text { without enframing }\end{array}$ & 6 & 7 & 2 & 2 \\
\hline Split-lot termination & 2 & 4 & 3 & 3 \\
\hline City center shops & 42 & 40 & 2 & 3 \\
\hline Churches & 3 & 2 & 2 & 0 \\
\hline $\begin{array}{l}\text { Schools / Library/ } \\
\text { Public buildings }\end{array}$ & 11 & 6 & 2 & 0 \\
\hline
\end{tabular}


Overall, Mariemont has a stronger correspondence between the number of the Unwin-inspired spatial elements in the "as-designed" and "as-built" conditions of the plan than does Windsor Farms. This higher fidelity of the buildout to the design is likely related to the buildout occurring closer to the time of Nolen's involvement in Mariemont, and the financial difficulties surrounding the latter 1920's and 1930's buildout of Windsor Farms.

It must be said that Mary Emery's vision of "A National Exemplar" (Rogers, 2001) was a key factor in the rapid buildout of Mariemont. The attention to detail executed by Ms. Emery's project manager, Charles Livingood, in quickly retaining a number of architects who's body of work was consistent with the English Village aesthetic is an indicator of the desire to follow through on original design intentions. This is contrasted by Windsor Farms developer T.C. Williams investing very little in following through on Nolen's village intentions.

Clarence Perry (Perry, 1929) and Clarence Stein both grasped this need for anchoring new developments with public buildings as evidenced in their independent formulations of the "neighborhood unit" in 1929. Perry went so far as to call the school "the neighborhood capitol" deserving of a dignified site. $^{14}$

Progressive era planners such as John Nolen rarely held full control over the subdivision, village or new town they were designing. In Nolen's case, elements of the plan were frequently omitted during the "build-out" phase of the project. The omitted elements were typically public in nature, open space preserves, small greens, golf courses, neighborhood commercial centers and civic centers. One might speculate that the developers of these subdivisions, villages and new towns were less concerned with these land uses and more concerned with saleable residential lots. Yet Nolen and his associates understood that neighborhoods needed anchors and persisted in designing plans around them. Even with these losses, these towns and subdivisions remain highly desirable places to live. This may be due to the clarity of structure, clear hierarchy of streets, with strong lines of enclosure from the now-mature landscape elements that combine to present a place rich in detail - having a presence of many smaller places within a larger place. Andres Duany, (Unwin, 1909) in the Preface to the reprinting of Town Planning in Practice states "The communities that stand today as the result of its prescriptions are still successful in all the ways that matter. This can be said of Letchworth, Hampstead, and Welwyn in England and of Yorkship and Mariemont in the United States. These are all robust survivors having withstood the degradation of modernist Planning from the reductive diagrams of social-democratic Europe to the wholesale abdication of principle before North American 'market forces." Duany continues, speaking of Mariemont and its promise. "Mariemont, designed in 1926, is the only civic community within the featureless sprawl that surrounds Cincinnati, Ohio. As testimony that suburbia

\footnotetext{
${ }^{14}$ Perry, Clarence A. "Neighborhood and Community Planning" Volume VII Regional Plan of New York and it's environs, 1929, Committee on The Regional Plan of New York and its environs, NY, NY p. 17.
} 
could have been otherwise, this new town elegantly accommodates both the pedestrian and the modern complement of automobiles."

\section{References}

Unwin, Sir Raymond, "Town Planning in Practice: An Introduction to the Art of Designing Cities and Suburbs" Charles Scribner \& Sons, New York, 1909.

Whittick, Arnold, Encyclopedia of Urban Planning, McGraw Hill, NY, NY 1974.

Rogers, Millard F. Mariemont: building a new town in Ohio, Johns Hopkins University Press, Baltimore, MD 2001.

Perry, Clarence A. "Neighborhood and Community Planning” Volume VII Regional Plan of New York and its environs, 1929.

Nolen, John. Accession 2903 drawer 3 Rare and Manuscript Collection, Carl A. Kroch Library, Cornell University, Ithaca, New York, 1922.

Letter from John Nolen to Henry Morse dated April 20, 1926. (Accession 2903 Box 66, Windsor Farms File, Rare and Manuscript Collection, Carl A. Kroch Library, Cornell University, Ithaca, New York.)

Road types diagrams. Permission by Kroch Memorial Library. (Accession 2903 drawer 3 Rare and Manuscript Collection, Carl A. Kroch Library, Cornell University, Ithaca, New York.) 